\title{
Phenological stages of some grapevine cultivars in North Serbia: Historical data and current state
}

\author{
D. Ivanišević ${ }^{1}$, M. Kalajdžić ${ }^{1}$, T. Alesandar ${ }^{2}$, and D. Jakšić ${ }^{3}$ \\ ${ }^{1}$ University of Novi Sad, Faculty of Agriculture, Dositeja Obradovića Squre 8, 21000 Novi Sad, Serbia \\ ${ }^{2}$ Ministry Of Agriculture, Forestry And Watermanagment, Omladinskih brigada 1, 11000 Belgrade, Serbia \\ ${ }^{3}$ Center For Viticulture And Oenology Niš, Bul. kralja Aleksandra 84, 11000 Belgrade, Serbia
}

\begin{abstract}
Phenological stages of many grapevine cultivars appear in earlier parts of the year. However, we do not know how different cultivars are affected by this trend. The aim of this study was to compare the phenological stages of grapevine cultivars recorded in two different periods (1986-1998 and 2013-2018) in North Serbia (Vojvodina). The investigation was carried out on five red (Cabernet sauvignon, Merlot, Pinot noir, Prokupac, Probus) and five white cultivars (Chardonnay, Muscat ottonel, Riesling italico, Smederevka and Petra). The phenological observations included the beginning of budburst, flowering and veraison. The beginning of all phenological stages in all cultivars in the period (2013-2018) occurred in earlier parts of the year, compared to the historical data. Local cultivars (Prokupac, Probus, Smederevka and Petra) showed less shift of the beginning of budburst in respect to the historical data (only six days earlier) compared to the international cultivars. One of the most important phenological stages, flowering, has been shifted ten days in the earlier part of the year. The biggest differences were observed for the beginning of veraison. Now, it occurs earlier from 9 (Petra) to 17 days (Merlot). Duration of the period from budburst to flowering was inconsistent and cultivars required almost the same number of days as it was in the past. However, the duration between flowering and veraison was shorter in the last six years. The biggest difference was observed in Merlot where the period between flowering and veraison has been seven days shortened.
\end{abstract}

\section{Introduction}

Phenological studies based on the long-term data set are important in determining the vine cultivars suitability for a given climate regime. Through studying grapevine phenology, the effect of climate change on grapevine has been evaluated over recent decades in many regions [1-4].

In most of the wine regions worldwide, it is a challenge to produce high quality wine. Among many environmental factors, climate has the greatest impact on phenology and therefore on grape quality. The optimum development of quality fruit for wine production is tied to phenological occurrence and timing $[5,6]$. Wineproducing regions are characterized by mean climatic conditions which are major drivers of wine quality in relation to its origin [7]. Climate characteristics of North Serbia (Vojvodina) and its wine regions are presented in papers $[8,9]$.

However, in a given wine region these conditions vary from year to year. Climatologists forecast an increase in air temperature by the end of the XXIst century, depending on the rate of greenhouse gas emissions [10]. Serbia, which is in the south-east part of Europe at Balkan Peninsula, is experiencing warming trend with accelerated temperature increase [11].

Currently, 190 varieties are present in the Serbian national vine register. However, only 10 varieties, mostly "international", represent $70 \%$ of the total surface area (22150 ha) [12]. The areas planted with "local" varieties are on the increase.

Phenology of some grapevine cultivars in Serbia has been previously analyzed [13], but cultivar respond to climate conditions was not disscused. Growing cultivars less sensitive to climatic variables offer an adaptation option to climate change.

The aim of this study was to compare the phenological stages of some grapevine cultivars recorded in two different periods (1986-1998 and 2013-2018) in North Serbia (Vojvodina).

\section{Material and methods}

The phenological observations were made over a six-year period at the Experimental filed of the University of Novi Sad, Faculty of Agriculture, situated in Sremski Karlovci - Fruska Gora wine region $\left(45^{\circ} 10^{\prime} \mathrm{N}, 20^{\circ} 10^{\prime} \mathrm{E}\right)$.

The investigation was carried out on five red (Cabernet sauvignon, Merlot, Pinot noir, Prokupac, Probus) and five white cultivars (Chardonnay, Muscat ottonel, Riesling italico, Smederevka and Petra). Prokupac, Probus, Smederevka and Petra are Serbian cultivars.

The collection was initially planted in 1979, and during 2007 the collection was completely replanted in a block next to the original vineyard (same soils), and 


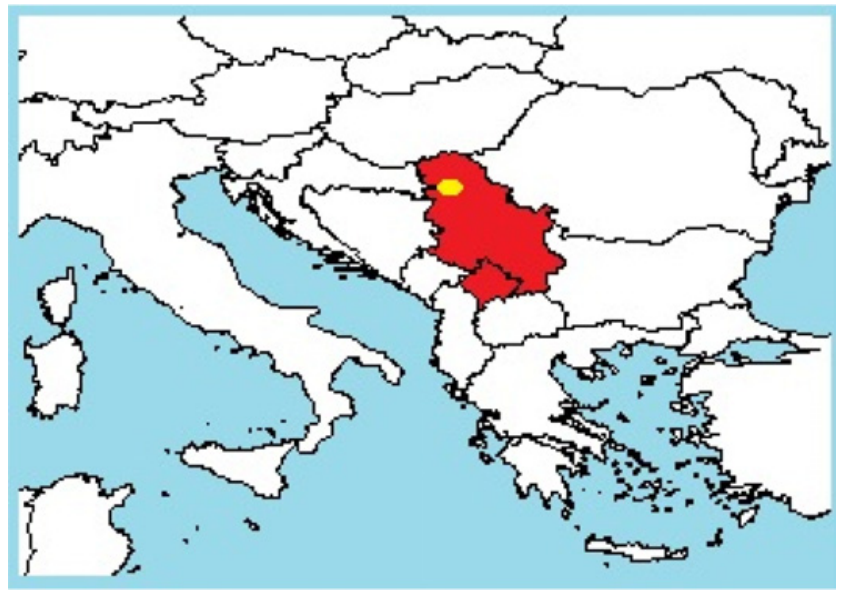

Figure 1. The map of Serbia and its wine region Fruska Gora.

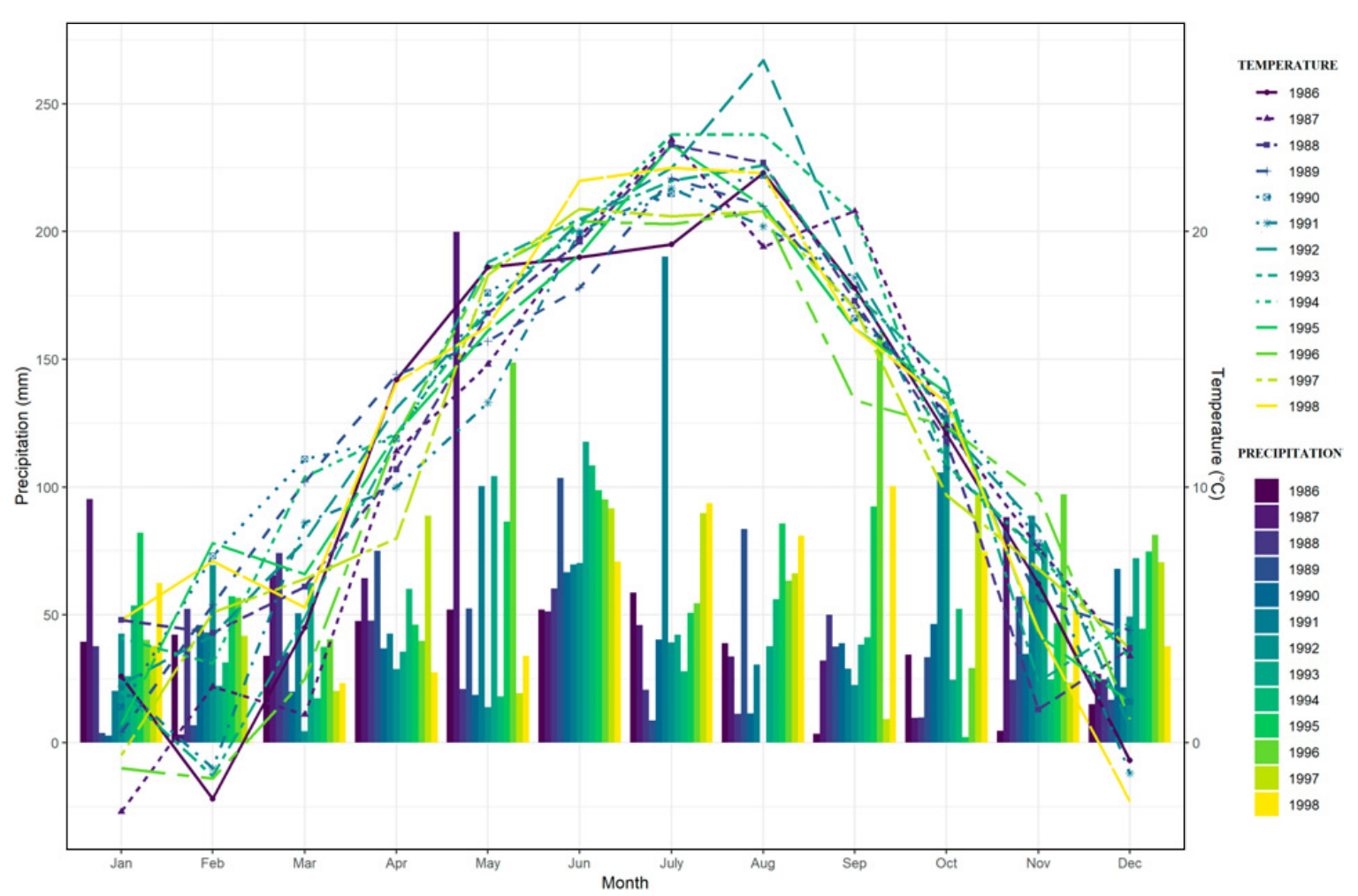

Figure 2. Climate conditions (average temperature and precipitation) in Sremski Karlovci for the period 1986-1998.

after four years the yearly phenological observations came from the new collection. Vines were trained to Guyot training system with one cane and one spur (14 buds per vine).

We examined three key phenological stages that were defined on the basis of the BBCH-scale [14]: $\mathrm{BBCH}-07$ corresponding to the beginning of budburst, that is the date when green shoot tips became visible; $\mathrm{BBCH}-60$ corresponding to the beginning of flowering, that is the date when first flower hoods were detached from the receptacle; and $\mathrm{BBCH}-81$ corresponding to the beginning of veraison, that is the date when the first green berries changed color.

Figures were prepared in statistical program R using the package ggplot2.

\section{Results and discussion}

Climate conditions (1986-1996)

High difference in average temperature among the years was observed in March (Fig. 2). The lowest temperature was in $1987\left(1.1^{\circ} \mathrm{C}\right)$, while the highest was in 1990 $\left(11.1^{\circ} \mathrm{C}\right)$.

In 1997, April was the coldest with an average temperature of $8.0^{\circ} \mathrm{C}$. In August 1993, the temperature was extremely high. The highest difference in precipitation among the months was observed in May. In 1991, extremely high precipitation was recorded in July.

Climate conditions (2013-2018) 


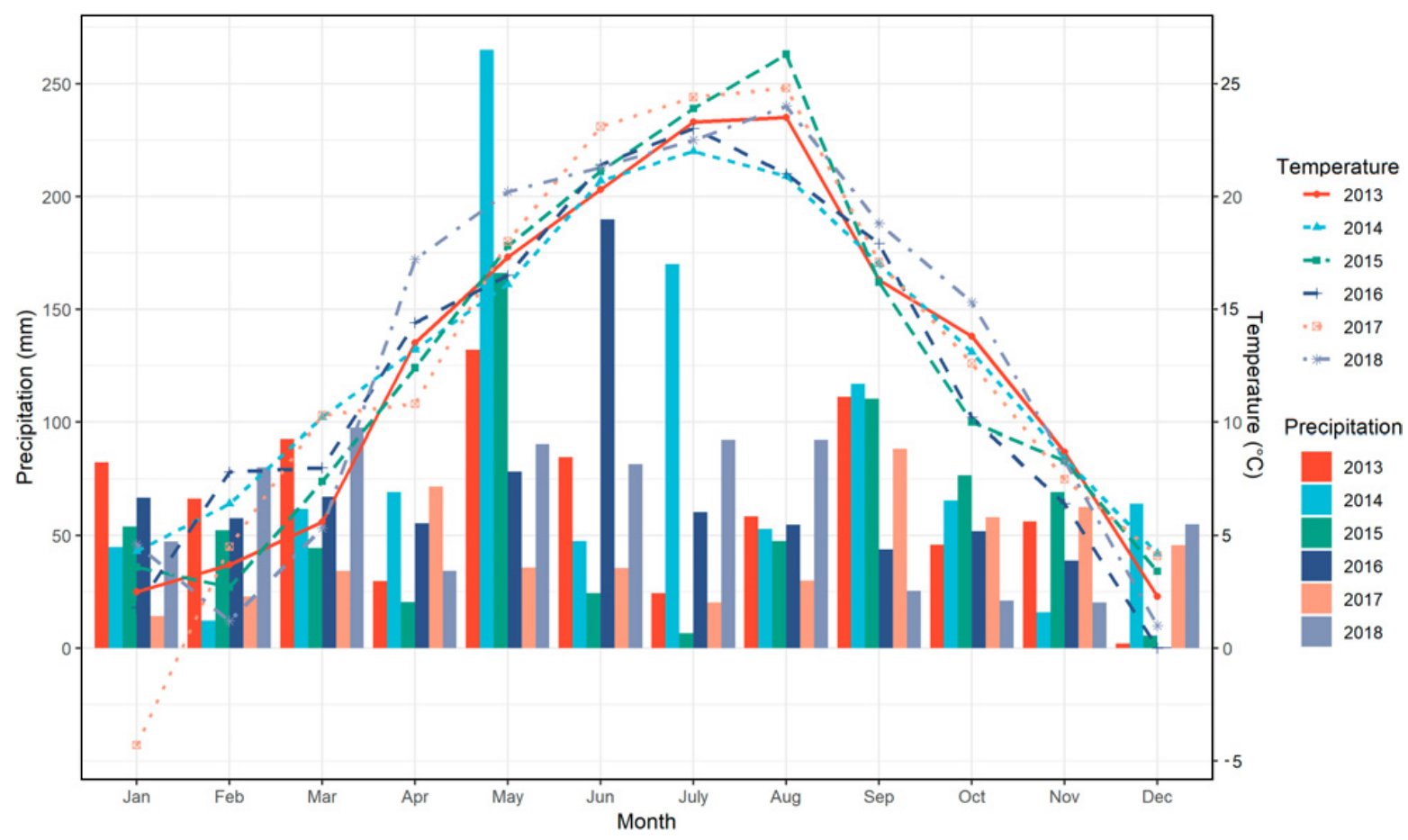

Figure 3. Climate conditions (average temperature and precipitation) in Sremski Karlovci for the period 2013-2018.

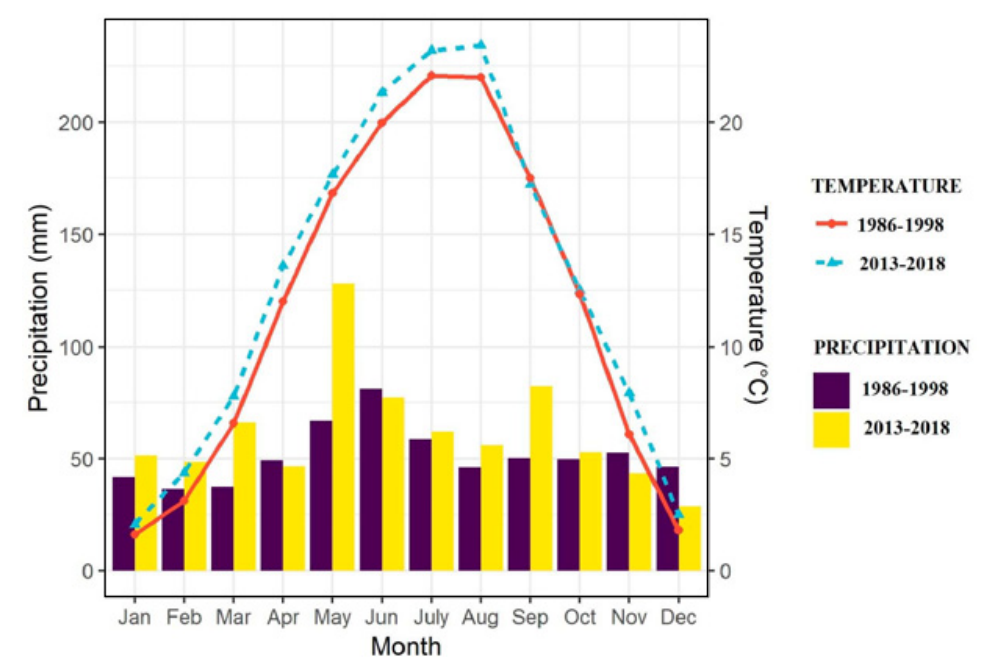

Figure 4. Average climate conditions for the periods 1986-1998 and 2013-2018.

Season 2014 was extremely rainy, especially in May and July (Fig. 3). 2013, 2015 and 2016 were dry and hot. 2017 was extremely hot during the summer. Spring in 2018 was significantly hotter compared to other seasons.

Average temperatures in period 2013-2018 were higher compared to 1986-1998 (Fig. 4). Precipitation amount in May for the period 2013-2018 was almost twice higher compared to $1986-1998$.

The beginning of all phenological stages in all cultivars (Tables 1 and 2) in the period (2013-2018) occurred in earlier parts of the year, compared to the historical data. Local cultivars (Prokupac, Probus, Smederevka and Petra) showed less shift of the beginning of budburst in respect to the historical data compared to the international cultivars. One of the most important phenological stages, flowering, has been shifted ten days in the earlier part of the year. In Sremski Karlovci, the beginning of flowering exhibited the least inter-annual variation [13]. The biggest differences were observed for the beginning of veraison. Now, it occurs earlier from 9 (Petra) to 17 days (Merlot). Many authors also showed that the main phenological stages (budbreak, flowering and veraison) have advanced significantly in the last few decades $[15,16]$. Grapes now ripen at temperatures that are approximately $1.2-1.8^{\circ} \mathrm{C}$ higher than a few decades ago [17]. For early ripening varieties, the temperatures are predicted to become too hot to produce high-quality wines.

Duration of the period from budburst to flowering was inconsistent and cultivars required almost the same number of days as it was in the past. However, the duration between flowering and veraison was shorter in the last six years. The biggest difference was observed in Merlot where the 
Table 1. Descriptive statistics of phenological stages for selected red grapevine cultivars for the periods 1986-1998 and 2013-2018 in Sremski Karlovci, Serbia.

\begin{tabular}{|c|c|c|c|c|c|c|c|}
\hline Phenological stages & Period & $\begin{array}{l}\text { Statistics } \\
\text { (date) }\end{array}$ & $\begin{array}{l}\text { Cabernet } \\
\text { sauvignon }\end{array}$ & Merlot & Pinot noir & Prokupac & Probus \\
\hline \multirow{2}{*}{ Beginning of budburst } & 1986-1998 & $\begin{array}{l}\text { Mean } \\
\text { Max } \\
\text { Min }\end{array}$ & $\begin{array}{l}\text { 20. April } \\
\text { 01. May } \\
\text { 07. April }\end{array}$ & $\begin{array}{l}\text { 17. April } \\
\text { 29. April } \\
\text { 04. April }\end{array}$ & $\begin{array}{l}\text { 15. April } \\
\text { 29. April } \\
\text { 04. April }\end{array}$ & $\begin{array}{l}\text { 12. April } \\
\text { 30. April } \\
\text { 21. March }\end{array}$ & $\begin{array}{l}\text { 19. April } \\
\text { 30. April } \\
\text { 6. April }\end{array}$ \\
\hline & 2013-2018 & $\begin{array}{l}\text { Mean } \\
\text { Max } \\
\text { Min } \\
\end{array}$ & $\begin{array}{l}\text { 11. April } \\
\text { 21. April } \\
\text { 4. April }\end{array}$ & $\begin{array}{l}\text { 5. April } \\
\text { 16. April } \\
\text { 27. March }\end{array}$ & $\begin{array}{l}\text { 5. April } \\
\text { 16. April } \\
\text { 27. March }\end{array}$ & $\begin{array}{l}\text { 6. April } \\
\text { 16. April } \\
\text { 24. March }\end{array}$ & $\begin{array}{l}\text { 10. April } \\
\text { 21. April } \\
\text { 03. April }\end{array}$ \\
\hline \multirow[b]{2}{*}{ Beginning of flowering } & 1986-1998 & $\begin{array}{l}\text { Mean } \\
\text { Max } \\
\text { Min }\end{array}$ & $\begin{array}{l}\text { 03. June } \\
\text { 16. June } \\
\text { 24. May }\end{array}$ & $\begin{array}{l}\text { 01. June } \\
\text { 16. June } \\
\text { 22. May }\end{array}$ & $\begin{array}{l}\text { 29. May } \\
\text { 13. June } \\
\text { 20. May }\end{array}$ & $\begin{array}{l}\text { 01. June } \\
\text { 15. June } \\
\text { 23. May }\end{array}$ & $\begin{array}{l}\text { 5. June } \\
\text { 18. June } \\
\text { 27. May }\end{array}$ \\
\hline & 2013-2018 & $\begin{array}{l}\text { Mean } \\
\text { Max } \\
\text { Min }\end{array}$ & $\begin{array}{l}\text { 24. May } \\
\text { 29. May } \\
\text { 16. May }\end{array}$ & $\begin{array}{l}\text { 22. May } \\
\text { 26. May } \\
\text { 12. May }\end{array}$ & $\begin{array}{l}\text { 20. May } \\
\text { 25. May } \\
\text { 10. May }\end{array}$ & $\begin{array}{l}\text { 22. May } \\
\text { 29. May } \\
\text { 11. May }\end{array}$ & $\begin{array}{l}\text { 24. May } \\
\text { 29. May } \\
\text { 10. May }\end{array}$ \\
\hline \multirow{2}{*}{ Beginning of verasion } & 1986-1998 & $\begin{array}{l}\text { Mean } \\
\text { Max } \\
\text { Min }\end{array}$ & $\begin{array}{l}\text { 05. August } \\
\text { 17. August } \\
\text { 28. July }\end{array}$ & $\begin{array}{l}\text { 04. August } \\
\text { 20. August } \\
\text { 20. July }\end{array}$ & $\begin{array}{l}\text { 25. July } \\
\text { 12. August } \\
\text { 13. July }\end{array}$ & $\begin{array}{l}\text { 02. August } \\
\text { 15. August } \\
\text { 26. July }\end{array}$ & $\begin{array}{l}\text { 7. August } \\
\text { 21. August } \\
\text { 30. July }\end{array}$ \\
\hline & 2013-2018 & $\begin{array}{l}\text { Mean } \\
\text { Max } \\
\text { Min }\end{array}$ & $\begin{array}{l}\text { 24. July } \\
\text { 28. July } \\
\text { 16. July }\end{array}$ & $\begin{array}{l}\text { 18. July } \\
23 \text {. July } \\
14 \text {. July }\end{array}$ & $\begin{array}{l}\text { 12. July } \\
\text { 14. July } \\
07 . \text { July }\end{array}$ & $\begin{array}{l}\text { 20. July } \\
\text { 26. July } \\
11 \text {. July }\end{array}$ & $\begin{array}{l}\text { 23. July } \\
01 \text {. August } \\
\text { 17. July }\end{array}$ \\
\hline
\end{tabular}

Table 2. Descriptive statistics of phenological stages for selected white grapevine cultivars for the periods 1986-1998 and $2013-2018$ in Sremski Karlovci, Serbia.

\begin{tabular}{|c|c|c|c|c|c|c|c|}
\hline Phenological stages & Period & $\begin{array}{l}\text { Statistics } \\
\text { (date) }\end{array}$ & Chardonnay & $\begin{array}{l}\text { Muscat } \\
\text { Ottonel }\end{array}$ & $\begin{array}{l}\text { Riesling } \\
\text { italico }\end{array}$ & Smederevka & Petra \\
\hline \multirow{2}{*}{ Beginning of budburst } & 1986-1998 & $\begin{array}{l}\text { Mean } \\
\text { Max } \\
\text { Min }\end{array}$ & $\begin{array}{l}\text { 11. April } \\
\text { 26. April } \\
\text { 21. March }\end{array}$ & $\begin{array}{l}\text { 14. April } \\
\text { 30. April. } \\
\text { 26. March }\end{array}$ & $\begin{array}{l}\text { 14. April } \\
\text { 29. April } \\
\text { 25. March }\end{array}$ & $\begin{array}{l}\text { 10. April } \\
\text { 26. April } \\
\text { 20. March }\end{array}$ & $\begin{array}{l}\text { 14. April } \\
\text { 27. April } \\
\text { 29. March }\end{array}$ \\
\hline & 2013-2018 & $\begin{array}{l}\text { Mean } \\
\text { Max } \\
\text { Min }\end{array}$ & $\begin{array}{l}\text { 2. April } \\
\text { 15. April } \\
\text { 25. March }\end{array}$ & $\begin{array}{l}\text { 04. April } \\
\text { 15. April } \\
\text { 22. March }\end{array}$ & $\begin{array}{l}\text { 08. April } \\
\text { 19. April } \\
\text { 30. March }\end{array}$ & $\begin{array}{l}\text { 02. April } \\
\text { 14. April } \\
\text { 22. March }\end{array}$ & $\begin{array}{l}\text { 04. April } \\
\text { 17. April } \\
\text { 25. March }\end{array}$ \\
\hline \multirow{2}{*}{ Beginning of flowering } & 1986-1998 & $\begin{array}{l}\text { Mean } \\
\text { Max } \\
\text { Min }\end{array}$ & $\begin{array}{l}\text { 29. May } \\
\text { 12. June } \\
\text { 18. May }\end{array}$ & $\begin{array}{l}\text { 01. June } \\
\text { 16. June } \\
\text { 22. May }\end{array}$ & $\begin{array}{l}\text { 02. June } \\
\text { 16. June } \\
\text { 24. May }\end{array}$ & $\begin{array}{l}\text { 01. June } \\
\text { 14. June } \\
\text { 22. May }\end{array}$ & $\begin{array}{l}\text { 28. May } \\
\text { 03. June } \\
\text { 23. May }\end{array}$ \\
\hline & 2013-2018 & $\begin{array}{l}\text { Mean } \\
\text { Max } \\
\text { Min }\end{array}$ & $\begin{array}{l}\text { 17. May } \\
\text { 25. May } \\
\text { 03. May }\end{array}$ & $\begin{array}{l}\text { 22. May } \\
\text { 28. May } \\
\text { 05. May }\end{array}$ & $\begin{array}{l}\text { 23. May } \\
\text { 27. May } \\
\text { 13. May }\end{array}$ & $\begin{array}{l}\text { 21. May } \\
\text { 26. May } \\
\text { 15. May }\end{array}$ & $\begin{array}{l}\text { 20. May } \\
\text { 25. May } \\
\text { 09. May }\end{array}$ \\
\hline \multirow{2}{*}{ Beginning of verasion } & 1986-1998 & $\begin{array}{l}\text { Mean } \\
\text { Max } \\
\text { Min }\end{array}$ & $\begin{array}{l}\text { 27. July } \\
\text { 08. August } \\
\text { 19. July }\end{array}$ & $\begin{array}{l}\text { 26. July } \\
07 \text {. August } \\
\text { 19. July }\end{array}$ & $\begin{array}{l}\text { 05. August } \\
\text { 17. August } \\
\text { 30. July }\end{array}$ & $\begin{array}{l}\text { 04. August } \\
\text { 20. August } \\
\text { 22. July }\end{array}$ & $\begin{array}{l}\text { 02. August } \\
\text { 12. August } \\
\text { 27. July }\end{array}$ \\
\hline & 2013-2018 & $\begin{array}{l}\text { Mean } \\
\text { Max } \\
\text { Min }\end{array}$ & $\begin{array}{l}\text { 13. July } \\
\text { 20. July } \\
\text { 05. July }\end{array}$ & $\begin{array}{l}\text { 13. July } \\
\text { 30. July } \\
17 \text {. June }\end{array}$ & $\begin{array}{l}\text { 22. July } \\
\text { 26. July } \\
\text { 19. July }\end{array}$ & $\begin{array}{l}\text { 20. July } \\
\text { 30. July } \\
\text { 11. July }\end{array}$ & $\begin{array}{l}\text { 24. July } \\
31 \text {. July } \\
\text { 21. July }\end{array}$ \\
\hline
\end{tabular}

period between flowering and veraison has been seven days shortened.

\section{Conclusion}

Changes in the phenology of several grape cultivars in recent decades are particularly in connection with the increase of temperature. The beginning of all phenological stages in all cultivars in the period (2013-2018) occurred in earlier parts of the year, compared to the historical data. One of the most important phenological stages, flowering, has been shifted ten days in the earlier part of the year. However, cultivars differently react to climate change. The biggest change in phenology was observed in Merlot where the period between flowering and veraison has been seven days shortened. Local cultivars were less affected by the weather conditions compared to the "international" cultivars. 


\section{References}

[1] I.P. Chuine, N. Yiou, B.S. Viovy, V. Daux, E.L. Ladurie, Nature 432, 289 (2004)

[2] F. Spanik, B. Siska, M. Galik, SHMÚ 4, 179 (2004)

[3] L.B. Webb, P.H. Whetton, E.W.R. Barlow, Aust. J. Grape Wine Res. 13, 165 (2008)

[4] C.A.I. de García, É. Duchêne, A. DestracIrvine, G. Barbeau, L. de Rességuier, T. Lacombe, A.K. Parker, N. Saurin, C. van Leeuwen, OENO One 51, 2 (2017)

[5] G.V. Jones, R.E. Davis, Am. J. Enology Vitic. 51, 249 (2000)

[6] M. Keller, Aust. J. Grape Wine Res. 16, 56 (2010)

[7] C. van Leeuwen, D. Philippe, JWE 11, 150 (2016)

[8] D. Ivanišević, A. Vuković, M.M. Vujadinović, N. Korać, D. Jakšić, P. La Notte, M. Kalajdžić, J. Koković, 11th International Terroir Congres (2016), P. 79

[9] J. Koković, M. Kalajdžić., D Ivanišević, N. Korać, A. Vuković, M.M. Vujadinović, D. Jakšić, P. La Notte, 11th International Terroir Congres (2016), p. 83
[10] IPCC, Climate Change. The Physical Science Basis. Contribution of Working Group I to the Fifth Assessment Report of the Intergovernmental Panel on Climate Change (New York, USA, Cambridge University Press, 2013)

[11] M. Unkasevic, I. Tosic, Int. J. Climatol. 33, 3152 (2013)

[12] D. Ivanišević, D. Jakšić, N. Korać, Atlas of Viticuture (Belgrade, Statistical Office of the Republic of Serbia, 2015)

[13] M. Ruml, N. Korać, D. Ivanišević, M. Vujadinović, A. Vuković, JOAS 58, 73 (2013)

[14] D.H. Lorenz, K.W. Eichhorn, H. Bleiholder, R. Klose, U. Meier, E. Weber, Aust. J. Grape Wine Res. 1, 100 (1995)

[15] E. Duchêne, C. Schneider, Agron Sustain Dev. 25, 93 (2005)

[16] D. Tomasi, G.V. Jones, M. Giust, L. Lovat, F. Gaiotti, Am. J. Enol. Vitic. 62, 329 (2011)

[17] S. Vršič, V. Šuštar, B. Pulko, T.K. Šumenjak, Clim. Res. 58, 257 (2014) 